\title{
Mapping the FACT-G to EQ-5D-3L utility index in cancer: data from a cross-sectional study in in Guangxi, China
}

\section{Research}

Keywords:

Posted Date: September 3rd, 2021

DOl: https://doi.org/10.21203/rs.3.rs-615349/v2

License: (c) (1) This work is licensed under a Creative Commons Attribution 4.0 International License. Read Full License 


\section{Abstract}

The full text of this preprint has been withdrawn by the authors since they no longer stand by the findings/conclusions of this work. Therefore, the authors do not wish this work to be cited as a reference. Questions should be directed to the corresponding author.

\section{Full Text}

The authors have withdrawn this preprint from Research Square. 